\title{
Two Generations of Diamonds in the Eclogite Xenoliths
}

\section{Zdislav V. Spetsius}

Institute of Diamond Industry, “ Almazy Rossii-Sakha “ Co Ltd., Mirny, Russia

\section{Introduction}

It is accepted most scientists that overwhelming majority of the diamonds are xenocrysts from mantle rock trapped by ascending kimberlitic or lamproitic magmas. Dating of mineral inclusions in diamonds (Richardson et al., 1984) and high aggregation state of nitrogen of single crystals suggest about ancient model ages of diamonds. However, nonuniform trace elements distribution in garnet inclusions (Shimizu and Sobolev, 1996), short residents time in mantle fibrous diamonds (Shrauder et al., 1995) and some other observations indicate a more young age of part of diamonds a relatively close to the time of kimberlite intruding. We have strong arguments that some diamonds were formed near the time of the kimberlite emplacement (Richardson et al., 1993). These data and some petrographic evidences (Spetsius, 1995b) suggest about multistage formation of diamonds in mantle. The proven diamonds source are various types of mantle rocks, but the relative proportion of eclogitic to peridotitic diamonds paragenesis widely varies in separate localities. This uncertainty and multistage diamonds population of kimberlites remain a topic of discussion and their decision is important for prospecting and exploration.

\section{Samples}

More than 500 samples of mantle diamondiferous xenoliths, mostly of eclogites, were found in Yakutian kimberlite province. Documentation of the assemblages reported here is based on binocular microscope observation of about 300 diamondiferous xenoliths from Udachnaya, Mir, Sytykanskaya and other pipes and detail investigation of diamonds and rocks from 70 samples of eclogites.

\section{Results}

Petrography: Diamond-bearing specimens are encountered in all compositions of mantle eclogite rocks: bimineral eclogites of ferrous and magnesian series, kyanite and corundum eclogites and also in garnet websterites. The diamondiferous eclogites do not stand out of the general series of mantle eclogites from kimberlite pipes either by specific properties, the composition of the minerals, or the distribution of elements between the coexisting garnets and pyroxenes. Intensive partial melting is characteristic feature for the most specimens. To some extent this is a typomorphic sign of diamondiferous eclogites from the Udachnaya pipe (Spetsius, 1995a). A selective enrichment in REE is observed in some xenolith minerals (high content of LREE in Cpx and HREE in Gt), what is explained due to a complicated metasomatic evolution (Spetsius and Griffin, 1997).

Diamonds: Usually 3-5 crystals are present in one xenolith, and rarely more than 1000 crystals (Spetsius, 1995a). The size of diamonds in xenoliths varies from micro- (less than 500 microns) to macrodiamonds (2-6 mm, sometimes more than $10 \mathrm{~mm}$ ). Mainly all diamonds are similar in size in each individual xenolith, but in collection of 70 samples 6 xenoliths contain both crystals as a large as about $5 \mathrm{~mm}$ together with diamonds of less than $0.5 \mathrm{~mm}$. In last cases, the microdiamonds are obviously connected with vein of partial melting products.

Crystals of octahedral or combined habit are more abundant in the eclogites from Yakutian kimberlites. In their morphology diamonds from xenoliths overlap all main types of diamonds in kimberlites. All diamonds in one sample usually have the same morphology. Two types of diamonds are present in rare cases. Cubic crystals are more abundant in eclogites from the Udachnaya pipe than in the total population of diamonds from this pipe. It is probably explained by peculiarities of mantle xenoliths recollection. 
Surface structures of crystals in eclogites are variable and mainly are similar to those of the kimberlite diamonds. As a rule diamonds show regular growth layers and a slight dissolution is observed only in rare samples. Nonuniform features are present in two xenoliths. Plastic deformation was observed in crystals from three xenoliths and is obviously connected with the direction of tectonic deformation in the whole rock.

Careful examination of the diamonds from about 70 xenoliths shows that $50 \%$ of macrodiamonds crystals $(>1 \mathrm{~mm})$ contain some visible inclusions. Usually there are a little tiny grains of opaque minerals. Sulfide inclusions are the most common. Silicate inclusions are rare. The diamonds in some specimens have sulfide rims around them.

\section{Discussion}

The complicated and multistage history of growth has been noted for part of diamonds as peridotitic and eclogitic paragenesis, that is manifested in zonal growth of diamonds and resorption, deformation or cleavage of crystals and their later regrowth (Spetsius, 1995b). The results of investigation of large octahedral diamond crystals (Bulanova, 1995), show that their central zones may have different shape: cubic, rounded, cubo-octahedral or octahedral. This evidences that diamonds have a multistage and interrupted growth, which responds to environmental and P-T condition changes and probably to variations in volatile components. Some petrologic evidence for multistage formations of diamonds in kimberlites and mantle xenoliths were summarized by Spetsius (1995b) and are as follows: (1) sharp boundaries between zones having different nitrogen content and aggregations stages in some diamonds; (2) big variation and difference in carbon isotope composition of inner and outer parts of crystals; (3) abundance of sulfides as inclusions in diamonds and heterogeneity of sulphur isotope compositions; (4) regularities of inclusions distribution in volume of crystals; (5) finding of combined associations of eclogitic and peridotitic paragenesis inclusions in one crystal.

Observation of diamonds in separate eclogites shows that there are some differences not only in their size but and in other characteristics: i) macrodiamonds in some cases are distributed parallel to direction of stress deformation and they have traces of plastic deformation; ii) macrodiamonds contain inclusions of silicate minerals more often than microdiamonds; iii) macro- and microdiamonds can be different in their colour, morphology and physical properties. A distinct evidence that part of diamonds in eclogites originate after formation of their major minerals provide such features: a) distribution of diamonds around large grains of garnet, b) relationship of diamonds location with zones of the rock deformation; c) correlation between the availability of diamonds and the intensity of partial melting of samples.

The multistage formation of diamonds in kimberlites, petrographic study of eclogite xenoliths, mineralogy and other properties of diamonds from eclogites (Spetsius, 1995a) allow to conclude about at least two stages of diamond growth in eclogites from the Udachnaya and other pipes of central part of Yakutian kimberlite province.

The diamonds of the first generation include the octahedron and dodecahedron crystals or their combination. They are crystallized simultaneously with rockforming minerals of eclogites in near-equilibrium and stable PT-conditions. In separate xenoliths these diamonds show a complicated history: they are resorbed or sometimes plastically deformed. Morphology, surface features, inner structures (Bulanova, 1995; Sunagava, 1984) and other properties of such crystals allow to conclude that the first generation diamonds are formed by the spiral mechanism and more likely that they grow in sulfide-silicate liquid or solution which was weakly supersaturated in carbon.

The diamonds of the second generation are mostly octahedral microdiamonds, cubes or coated diamonds. Some crystals have a rather obvious features of hopper and skeleton growth and they captured the secondary mineral phases of eclogites as inclusions. These features and other petrographic evidences suggest that part of diamonds in eclogites grew simultaneously with the metasomatic minerals. They have formed in unstable and non-equilibrium conditions 
sometimes by abnormal mechanism of growth under conditions with a high degree of carbon supersaturation. Diamonds were grown in a sulfide-silicate melt rich in fluid or probably in some cases have crystallized from fluid. Such conditions may be realized by partial melting of eclogite xenoliths.

The melting process in eclogites can be initiated by a temperature increase, pressure decrease, or by the pervasive infiltration of fluid phases, such as water and/or $\mathrm{CO}_{2}$. There are some evidences that these two last factors were responsible for the partial melting of eclogites. A number of facts show that by the crystallization of diamonds the sulfides were present together with the silicates in melt. The mechanism of diamond growth should be discussed in a complex sulfide-silicate system where the transition metals may catalyze the crystallization process. The sulfide melt remains as a liquid by rather less temperature than silicate and sulfides reduce the beginning-of-melting and diamond growth temperatures in eclogites.

\section{Conclusion}

Petrologic evidence and observation of eclogite xenoliths from the pipes of central part of Yakutian kimberlite province suggest about two disconnected in time generations of diamonds in eclogites different in PT-conditions and environment of their origin.

First generation of diamonds in eclogites is presented usually by octahedral macrodiamonds with rare inclusions. The crystallization of these diamonds took place in stable PT-conditions of upper mantle from sulfide-silicate liquid or solution.

Second generation of diamonds is presented by octahedral microdiamonds, cubic or coated crystals. It is noteworthy metastable growth of crystals. Obvious connection of these diamonds growth with partial melting or metasomatic processes is observed. The growth of the second generation diamonds took place in low and metastable PT-conditions. The crystallization had origin in sulfide-silicate fluid-rich melt or in fluid.

\section{References}

Bulanova, G.P., 1995, The formation of diamond: Journal of Geochemical Exploration, v. 53, p. 1-23.

Richardson, S.H., Harris, J. W., and Garney, J. J., 1993, Three generations of diamonds from old continental mantle: Nature, v. 366, p. 256.-258.

Richardson, S. H. , Gurney, J. J. , Erlank, A. J. , and Harris, J. W. 1984. Origin of diamonds in old enriched mantle. Nature, 310:198-202

Shimizu, N., and Sobolev, N. V., 1995, Young peridotitic diamonds from the Mir kimberlite pipe: Nature, v. 375, p. 394-397.

Shrauder, M., Koeberi, C., and Navon, O, 1995, Trace element analyses of fluid-bearing diamonds from Jwaneng, Botswana: Geochim. et Cosmochim. Acta, v. 60, p. 4711-1724.

Spetsius, Z. V., 1995a, Occurrence of diamond in the mantle: a case from the Siberian Platform. Journal of Geochemical Exploration, v. 53, p. 25-39.

Spetsius, Z. V., 1995b, Diamondiferous eclogites from Yakutia: Evidence for a late and multistage formation of diamonds: 6th IKC Abstracts, Novosibirsk, p. 572-574.

Spetsius, Z.V., and Griffin, W.L., 1997, Trace elements in minerals from eclogites from Udachnaya kimberlite pipe, Yakutia: Russian Geol. and Geophysics, v. 38, p. 240-246.

Sunagawa, I., 1984, Growth of crystals in nature. In: I.Sunagawa (Editor) Materials Science of the Earth's Interior, Tokyo, 61-103. 